\title{
RANCANG BANGUN MESIN PERAJANG KERUPUK JENGKOL UNTUK MENINGKATKAN PENDAPATAN UKM
}

\author{
${ }^{1)}$ Sugiyanto, ${ }^{2)}$ Juni Trisnowati \\ ${ }^{1)}$ Program Studi Teknik Mesin, Universitas Surakarta \\ Jl. Raya Palur Km.05, Surakarta \\ ${ }^{2)}$ Program Studi Ekonomi Universitas Surakarta \\ Jl. Raya Palur Km.05, Surakarta \\ ${ }^{1)}$ Email: sugiyantoputro@yahoo.co.id
}

\begin{abstract}
ABSTRAK
Kerupuk jengkol merupakan makanan tambahan sebagai pelengkap hidangan. Kerupuk jengkol banyak sekali penggemarnya dari kalangan anak-anak, muda dan orang tua. Hal ini disebabkan kerupuk jengkol itu renyah serta gurih dan dapat menyesuaikan jenis hidangan yang disantap. Disekitar kita banyak sekali tentang jenis kerupuk jengkol yaitu kerupuk jengkol yang berbentuk lingkaran. Hampir semua pembuat kerupuk jengkol, khususnya kalangan menengah kebawah dapat dikatakan sangat memerlukan sentuhan teknologi dalam pemotongan gendar kerupuk jengkol. Kebutuhan akan kerupuk jengkol oleh masyarakat semakin bertambah, sedang industri pembuat kerupuk jengkol belum dapat mengimbangi akan kebutuhan konsumen. Sampai sekarang industri kecil dalam hal proses pemotongan gendar kerupuk jengkol masih manual, yaitu memakai pisau sehingga hasil yang didapatkan sedikit, tidak seragam dan waktu yang dibutuhkan lama dan proses pengadukan. Hal inilah yang menyebabkan kebutuhan akan kerupuk jengkol untuk dikonsumsi terbatas. Bagi industri kecil kesulitan tersebut diatas belum terpecahkan, sehingga diperlukan inovasi program pengembangan Teknologi, khususnya proses pemotongan gendar kerupuk jengkol. Tujuan utama dari kegiatan ini adalah membuat mesin pemotong gendar kerupuk jengkol dan mesin pengaduk yang mampu bekerja secara efektif, sehingga meringankan beban UKM. Metode yang ditawarkan: Survey, perancangan komponen, desain mesin, pembuatan, pengujian mesin, evaluasi, pembuatan laporan. Hasil yang didapatkan mesin ini adalah 10 batang gendar kerupuk rambak seberat $5 \mathrm{~kg}$ proses pemotongan membutuhkan waktu 10 menit, karena proses pemotongan dengan menggunakan mesin. Dengan demikian hasil rekayasa dapat dikatakan dapat bekerja dengan baik, seperti yang diharapkan.
\end{abstract}

Kata kunci : gendar, mesin pemotong, kerupuk

\section{PENDAHULUAN}

Kecamatan Delanggu merupakan Wilayah Kecamatan yang masuk Kabupaten Klaten yang letaknya strategis, karena delanggu merupakan jalur propinsi lintas selatan sebagai ujung tombak pengembangan wilayah IV disebelah utara. Pada dasarnya masyarakat umumnya bermata pencaharian petani atau penggarap sawah. Masyarakat yang tidak mempunyai sawah, mereka bekerja sebagai pedagang, membuka usaha industri kerupuk dan wiraswasta. Masyarakat kedua desa tersebut, tidak patah semangat untuk membuka usaha baru yaitu pembuatan krupuk yang berbentuk bulat (Jengkol) sebagai usaha yang menjanjikan sampai sekarang. Usaha krupuk tersebut, antara kedua desa saling sinergi dan membantu dalam memenuhi kebutuhan kerupuk.

Usaha pembuatan kerupuk jengkol antara Desa Gatak dan Desa Dukuh sudah terakomodir dengan baik, walaupun belum sempurna terutama dalam pemenuhan order dalam hal pemanfaatan teknologi tepat guna dan cara manajemen produksi. Kelompok Industri Kerupuk Jengkol Mutiara ini terletak di Desa Kemasan, Gatak, Delanggu kurang lebih30 km dari kampus UNSA Surakarta ke 
arah Barat. Kelompok Industri Kerupuk Jengkol Mutiara ini letaknya strategis karena merupakan jalur arah Solo-Yogyakarta. Kelompok Industri Kerupuk Jengkol Mutiara ini berdiri tahun 2012 dengan beranggotakan 3 industri kecil yaitu Industri Kerupuk Jengkol Iwan Nugroho, Suwoto dan Supriyadi yang dipimpin olehIwan Nugroho. Industri kerupuk jengkol Kelompok Mutiara ini merupakan salah satu UKM yang mempunyai potensi untuk dikembangkan. Namun disisi lain teknologi yang untuk mendukung pengembangan tersebut masih belum maksimal. Dalam proses produksinya yang dijalankan masih sangat manual, yaitu dalam proses persiapan sampai pembuatan masih menggunakan tenaga manusia. Kelompok Industri Kerupuk Jengkol Mutiara ini terletak di DesaKemasan, Gatak, Delanggu kurang lebih $30 \mathrm{~km}$ dari kampus UNSA Surakarta ke arah Barat. Kelompok Industri Kerupuk Jengkol Mutiara ini letaknya strategis karena merupakan jalur arah Solo-Yogyakarta. Kelompok Industri Kerupuk Jengkol Mutiara ini berdiri tahun 2012 dengan beranggotakan 3 industri kecil yaitu Industri Kerupuk Jengkol Iwan Nugroho, Suwoto dan Supriyadi yang dipimpin olehIwan Nugroho. Industri kerupuk jengkolKelompok Mutiaraini merupakan salah satu UKM yang mempunyai potensi untuk dikembangkan. Namun disisi lain teknologi yang untuk mendukung pengembangan tersebut masih belum maksimal. Dalam proses produksinya yang dijalankan masih sangat manual, yaitu dalam proses persiapan sampai pembuatan masih menggunakan tenaga manusia. Menurut Pak Iwan Nugroho selaku pimpinan Kelompok Industri Kerupuk JengkolMutiara, bahwa 3 tahun terakhir ini ada peningkatan permintaan, terutama dari wilayah Sukoharjo, Klaten, Boyolali.

Pada hal kemampuan produksi dari Kelompok Industri Kerupuk Jengkol Mutiara terbatas. Sedangkan peranggota setiap harinya target terpenuhi sekitar 40-50 pak perhari. Namun target tersebut tercapai atas permintaan pasar, hal ini disebabkan untuk alat pendukung usaha tersebut tidak ada, dengan kata lain masih manual yaitu proses pemotong gendar krupuk jengkolnya. Kelompok Industri Kerupuk Jengkol Mutiara ini memperkerjakan 3-4 orang yang diambil dari sekitar rumahnya. Sehingga dalam satu minggu hanya dapat memenuhi permintaan konsumen sebanyak sebanyak 160-200 pak perminggu, hal ini masih jauh untuk mengembangkan industrinya.Oleh karena itu,hal ini menyebabkan Pak Iwan Nugroho selaku pimpinan kelompok memikirkan, bagaimana caranya untuk memecahkan masalah yang dihadapi anggotanya agar keluar dari kesulitan dalam memenuhi permintaan konsumen secara tepat dan hasil optimal.

Dari segi komunikasi antara industri kerupuk (kelompok) dengan pengguna sudah berjalan dengan lancar. Untuk transportasi sudah tidak ada masalah, karena setiap kelompok sudah menyediakan alat transportasi yang digunakan untuk memperlancar pasokan kerupuk disetiap daerah. Dengan permintaan pasar yang meningkat menjadikan peluang bagi Kelompok Mutiara yang dipimpin oleh Pak Iwan Nugroho untuk mengembangkan bisnisnya. Akan tetapi, untuk meningkatkan permintaan pasar mengalami hambatan yaitu proses pemotong gendar krupuk jengkolnyayang relatif lama, sehingga menyebabkan hasil potongan tidak sama, waktu yang dibutuhkan lama, mengakibatkan dapat dipastikan tidak akan dapat memenuhi kebutuhan pasar. Hasil potongan gendarnya dengan menggunakan pisau, proses pemotongan 1 batang kerupuk jengkol membutuhkan waktu 15 menit.

Untuk manajemen atau administrasi pembukuan yang dilakukan oleh kelompok mutiara masih sebatas tertulis pada buku kecil saja atau tidak diperhitungkan tentang bahan yang digunakan habis berapa, bumbu yang lain tidak dibukukan, yang penting ada kelebihan bisa untuk membayar pekerja dan kembali modal, serta untung. Jadi tentang bisnis plan pada kelompok ini belum tertata dengan baik.

Kelompok Mutiara dan Kelompok Kurnia sudah ada kesepakatan untuk saling mencukupi kekurangan stok hasil produksi kerupuk untuk pemenuhan kebutuhan. Terutama di bidang komunikasi, transportasi dan informasi kedua kelompok saling sinergi akan pemasaran setiap kelompok. Bidang manajemen kedua kelompok belum tertata dengan baik, selama ini proses penghitungan rugi laba masih manual belum terkomputerisasi. Oleh karena itu tim pengabdi untuk memperbaiki proses produksi dan sistem manajemen kedua kelompok agar tertata dengan benar secara modern, peningkatan produksi akan terkontrol. Pada saat proposal 
ini dibuat, bahwa Kelompok Industri Kerupuk Jengkol Mutiara mendapat permintaan kerupuk jengkol sebanyak 1 ton untuk dikirim ke Jakarta. Ini merupakan motivasi mitra untuk meningkatkan mutu, kualitas dan kapasitas produksi. Bahwa kelayakan suatu usaha dapat dilihat dari perhitungan analis usaha, Sedangkan analis tersebut bukan hanya sebatas perhitungan jumlah untung rugi yang diperoleh, tetapi mengenai biaya investasi, operasional, pengeluaran dan besarnya penerimaan.

Dalam pasokan bahan baku Kelompok Industri Kerupuk Jengkol tidak ada permasalahan. Adapun bahan baku yang dibutuhkan dalam pembuatan adonan kerupuk jengkol tersebut adalah pati, gandum dan air pada tiap harinya. Hasil campuran dimasukkan ke dalam plastik, kemudian dari bahan baku tersebut dimasak atau dikukus, kemudian ditampung dalam satu tempat. Selain itu juga, kedua kelompok mitra perlu untuk di perhatikan tentang teknologi yang dapat diterapkembangkan untuk meningkatkan pendapatan dan produktifitas oleh kedua kelompok tersebut. Secara khusus permasalahan yang dihadapi oleh kedua kelompok industi kerupuk jengkol adalah proses pemotongan gendar kerupuk jengkol yang tidak seragam, proses pencampuran adonan dan perbaikan manajemen yang masih tradisional. Dengan menyelesaikan dan memecahkan permasalahan tersebut diatas, dapat meningkatkan produksi, pendapatan dan manajemen yang baik dan tertata.

Tabel 1. Justifikasi tim pengusul dan mitra

\begin{tabular}{|c|c|}
\hline $\begin{array}{c}\text { Tim } \\
\text { Pengusul }\end{array}$ & $\begin{array}{l}\text { Lokasi mitra sangat strategis, } \\
\text { sehingga sangat tepat untuk } \\
\text { dikembangkan. } \\
\text { Produktivitas yang terus menerus, hal } \\
\text { dibuktikan peningkatan order yang } \\
\text { banyak. } \\
\text { Mitra tersebut sangat membutuhkan } \\
\text { sentuhan teknologi dan penataan } \\
\text { manajemen atas } \\
\text { Memfasilitasi mitra } \\
\text { permasalahan yang ada pada kedua } \\
\text { kelompok mitra dalam bentuk usulan } \\
\text { teknologi terapan. } \\
\text { Kelompok mitra kemampuan untuk } \\
\text { berkembang sangat baik }\end{array}$ \\
\hline $\begin{array}{c}\text { Kelompok } \\
\text { Mitra }\end{array}$ & $\begin{array}{l}\text { Pemotongan dengan pisau waktu } \\
\text { yang dibutuhkan lama, tidak seragam } \\
\text { Pengaduk adonan yang dapat merata } \\
\text { Manajemen yang baik } \\
\text { Menggunakan mesin secara benar } \\
\text { sesuai arahan tim pengusul }\end{array}$ \\
\hline
\end{tabular}

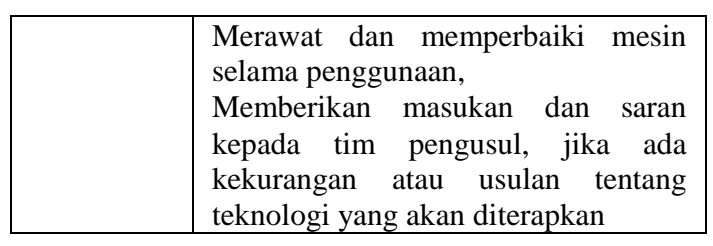

\section{TINJAUAN PUSTAKA}

Konsumsi kerupukdi Indonesia sangat besar,terbukti dari animo masyarakat yang begitu besar dan keberadaannya yang tersebar luas. Kerupuk ini sering digunakan sebagai makanan selingan dan pelengkap makanan nasi, bahkan tidak sedikit orang yang menganggap sebagai lauk-pauk setiap hari. Berdasarkan hasil penelitian yang dilakukan oleh Badan Penelitian dan Pengembangan Kesehatan Departemen Kesehatan RI, 2007, menyatakan bahwa, kerupuk merupakan kerupuk yang paling bergizi dibandingkan dengan dengan kerupuk tapioka, terigu dan kedelai. Kadungan yang ada didalamkerupukmeliputi $82,9 \%$ protein, $16 \%$ karbohidrat,3,84\% lemak per 100 gram serta $0,04 \%$ mineral.

\section{Perumusan Masalah}

Masalah utama yang dihadapi ke dua mitra tersebut adalah adanya pembuatan mesin pemotong, serta sistem administrasi dan pembukuan yang belum tertata dan masih manajemen kekeluargaan atau kata lain " yang penting untung " dan tidak bisa di mengerti berapa laba yang didapat setiap harinya.

\section{Tujuan dan Manfaat}

Tujuan utama dari kegiatan ini adalah merancang dan membuat mesin perajang yang mampu bekerja secara efektif yang digerakkkan dengan motor listik, mesin diesel dengan daya yang rendah sehingga meringankan beban UKM.

Manfaat kegiatan

a. Potensi sosial dan ekonomi produk.

Secara umum potensi ekonomi produk yang diperoleh antara lain: biaya pembuatan mesinmurah, daya yang digunakan kecil untuk listrik yang 450 Watt sehingga tidak memberatkan biaya pengoperasian. Mesin ini dapat dimanfaatkan oleh sekelompok mitra yang lain. Biaya yang ditanggung untuk kepemilikanpun semakin murah. Nilai 
ekonomis produk hasil pemotongan dan pengadukan juga cukup besar, dimana dengan menggunakan mesin ini, mitra diharapkan akan termotivasi dalam meningkatkan produktivitas dan order yang didapatkan akan terselesaikan dengan cepat.

b. Nilai tambah produk dari sisi IPTEK

Ditinjau dari sisi iptek, terdapat nilai tambah yaitu pemanfaatan teknologi tepat guna. Desain alat sederhana, namun mempunyai manfaat yang sangat tinggi. Pembuatan alat ini cukup hanya menggunakan mesin perkakas konvensional dan pengelasan, sehingga dapat dilakukan di bengkel kecil. Berdasarkan data hasil penelitian ini merupakan data penting dari rekayasawan dalam mengembangkan yang lebih lanjut. Hasil penelitian ini diinformasikan kepada masyarakat ilmiah dan masyarakat luas melalui majalah ilmiah tingkat nasional.

\section{c. Dampak sosial secara nasional}

Dampak sosial yang dirasakan ada 3 yaitu peningkatan produktifitas dan kualitas, peningkatan pendapatan para industri kecil, dan peningkatan order bagi pemilik bengkel teknologi tepat guna. Secara umum terlaksana program ini meningkatkan kesejahteraan masyarakat kalangan menengah ke bawah dan meningkatkan pendapatan, khususnya usaha/industri dan perbengkelan.

d. Nilai Tambah Bagi Perguruan Tinggi dan Pemerintah

Pelaksanaan program ini juga sekaligus akan menjadi jembatan kerjasama antara perguruan tinggi dan beberapa industri kecil, seperti industri kecil, Industri Perbengkelan Tepat Guna dan pemasok jagung. Program ini diharapkan terus berlanjut untuk didaerah lain, sehinggga dalam skala nasional program ini akan meningkatkan pendapatan perkapita daerah.

\section{METODOLOGI}

Secara umum tahapan langkah pelaksanaan program PKM pembuatan mesin perajang gendar kerupuk jengkol, dalam rangka mendukung program pemerintah tentang peningkatan budaya wirausaha masyarakat yaitu peningkatan produksi dan kualitas industri kecil.

Mesin perajang gendar kerupuk jengkol ini dirancang untuk meningkatkan produktifitas dalam merajang gendar melalui proses perajangan/pemotongan yang semula masih manual yaitu dengan pisau, sehingga proses perajangan atau pemotongan lmbat dan kapasitas sedikit. Mesin Pemotongan Gendar Kerupuk Jengkol tersebut dirancang dengan penggerak motor listrik. Putaran motor 1450 Rpm direduksikan dengan sistem transmisi Vbelt. Mesin ini dirancang dengan jumlah pisau 3 buah. Nampan dudukan gendar kerupuk jengkolterbuat dari bahan stenlees stell. Gendar kerupuk jengkol yang ditempatkan dalam nampan akan terdorong secara otomatis, dan pisau yang berputar secara otomatis akan memotong gendar tersebut.Pisau pemotong terbuat dari baja remanit yang tahan karat, sehingga higiens. Tempat nampan jatuhnya gendar kerupuk jengkolhasil potongan dibuat dari Stenless Steel. Direncanakan hasil yang di dapatkan dengan kapasitas $8 \mathrm{~kg} /$ menit.

Konstruksi rangka mesin dibuat dari baja profil L ST 37. Poros utama direncanakan dibuat dari baja ST 60 yang terdapat dipasaran. Semua komponen yang berputar ditutup, termasuk puli dan sabuk. Hal ini dilakukan untuk menjaga kemungkinan terjadinya kecelakaan selama pengoperasian mesin. Adapun langkah - langkah pelaksanaan program PKM ini adalah:

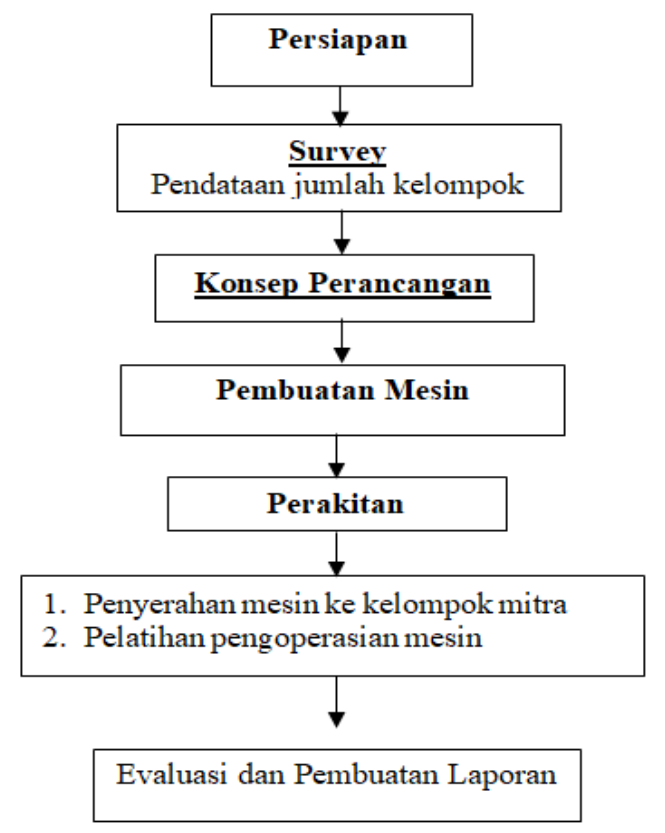

Gambar 1. Diagram alir kegiatan 
Pelatihan Manajemen Dan Pembukuan

Untuk mengetahui seberapa modal yang dikeluarkan dan laba yang dihasilkan setiap bulannya atau setiap produksi. Sebab selama ini masih memakai manajemen keluarga jadi tidak diketahui laba yang dihasilkan dari penjualan produksi kerupuk setiap harinya untuk mengenalkan sistem manajemen baru dan pembukuan keuangan sehingga seberapa besar laba maupun produk yang terjual hari ini bisa diketahui yang selama ini tidak adanya pembukuan dan memakai manajemen tradisional. Masyarakat akan tahu tentang manajemen kewirausahaan serta bisnis plan.

\section{HASIL DAN PEMBAHASAN}

\section{Kapasitas Mesin}

\section{Dalam proses Pemotong didapat hasil bahwa}

Sebelum menggunakan mesin hasil yang didapatkan :

a. 1 batang gendar kerupuk jengkol seberat $0,5 \mathrm{~kg}$ proses pemotongan membutuhkan waktu 15 menit, karena proses pemotongan dengan menggunakan pisau.

b. Hasil pemotongan tidak seragam

c. Sering terjadi kecelakaan kerja yaitu tangan teriris dengan tanpa sengaja.

- Sesudah menggunakan mesin hasil yang didapatkan :

d. 10 batang gendar kerupuk rambak seberat $5 \mathrm{~kg}$ proses pemotongan membutuhkan waktu 10 menit, karena proses pemotongan dengan menggunakan mesin

e. Hasil pemotongannya meningkat dan seragam

- Kecelakaan kerja tidak akan terjadi karena komponen pisau dan mesin tertutup.

Beberapa keunggulan, yaitu (1) mampu memotong dengan cepat dan seragam (2) mesin ini dapat dikembangkan untuk kapasitas yang lebih besar dengan melakukan modifikasi pada beberapa bagian tertentu. Sekalipun mesin tersebut mempunyai berbagai keunggulan, namun beberapa kelemahan mesin ini juga ada. Kelemahan inilah yang mendukung para pengabdi untuk selalu terus melakukan kegiatan pengabdian. Beberapa kelemahan tersebut adalah (1) mesin ini bebannya terlalu berat, (2) mesin ini belum otomatis yaitu operator dalam proses pemotongan.

Berdasarkan hasil di kedua mitra secara langsung, maka dapat dikatakan bahwa mesin pemotong sudah dapat bekerja dengan hasil seperti yang diharapkan. Mesin ini sekarang sudah langsung dipakai oleh mitra. Adapun kontribusinya mitra adalah merawat dan memperbaiki agar mesin dapat berjalan dengan baik.

Keberlanjutan program setelah kegiatan PKM selesai

Setelah program selesai dan evaluasi dilaksanakan, akan menjadikan tolak ukur tim pengusul untuk melanjutkan program yang lain. Secara berkala yaitu tiap 2 bulan sekali, tim mengadakan pemantauan tingkat pemakaian mesin, penerapan manajemen bisnisnya, apabila ada kerusakan yang bersifat teknis dan non teknis akan dapat diketahui. Dengan demikian tim pengusul dapat memantau keberhasilan program tersebut, sehingga dapat disebarluaskan kepada kelompok mitra yang lain.
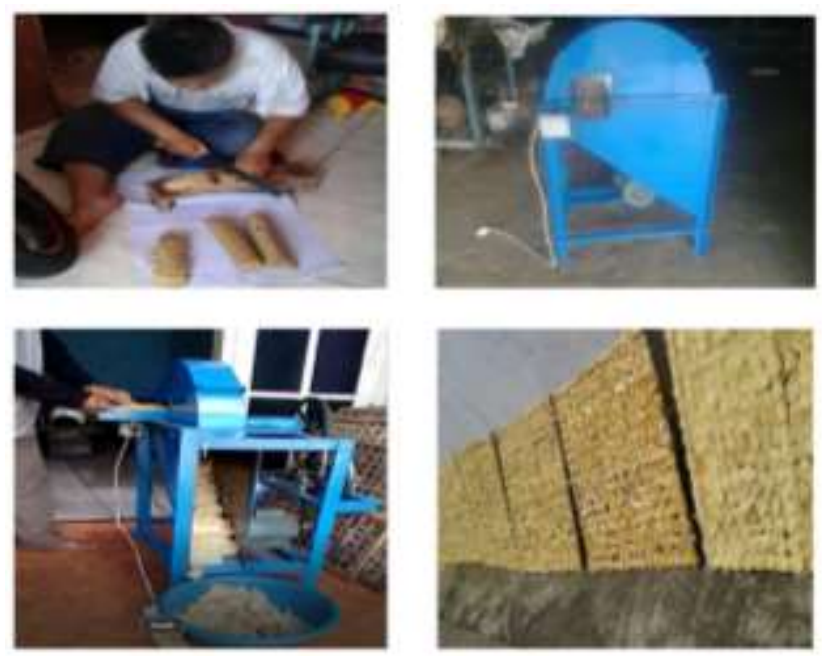

Gambar 2. Kegiatan pembuatan mesin perajang kerupuk

\section{KESIMPULAN}

a. Kesimpulan

- Hasil yang didapatkan mesin ini adalah 10 batang gendar kerupuk rambak seberat $5 \mathrm{~kg}$ proses pemotongan membutuhkan waktu 10 menit, karena proses pemotongan dengan menggunakan mesin. Dengan demikian hasil rekayasa dapat dikatakan dapat 
bekerja dengan baik, seperti yang diharapkan.

- Keberhasilan program ini akan menjadi lebih sempurna, jika dilakukan rekayasa Mesin yang lain dan berkelanjutan. Untuk kapasitas yang lebih besar, maka teknologi alat ini dapat dikembangkan lagi dengan modifikasi bagian tertentu sehingga menghasilkan kapasitas yang lebih banyak. Dalam perancangan mendatang, sebaiknya rekayasa Mesin pemotong berikutnya sudah menerapkan sistem otomatis.

b. Saran

- Mesin hasil rancangan dapat dipergunakan dengan benar

- Buku pedoman pengoperasian harus dibaca dan dimengerti

- Perawatan dan perbaikan mesin diperhatikan

\section{UCAPAN TERIMA KASIH}

Tim Pengabdi mengucapkan terima kasih kepada DRPM yang telah mendukung kegiatan pengabdian ini dengan baik.

\section{Daftar Pustaka}

Khurmy, R.S and Gupta, J.K ( 1982 ) “ Text Book of Machine Design ", Third Edition Eurasia Publishing House, New Delhi.

Suga, Kiyokatsu, Sularso, Dasar Perencanaan dan Pemilihan Elemen Mesin, Edisi ke -10 , PT. Pradnya Paramita, Jakarta 2000

BP2K Departemen Kesehatan RI, 2007, Konsumsi Makanan Ringan Bagi Masyarakat" Balai pustaka, Jakarta 